\title{
GÁTAK A MAGYAR VÁLLALATI NÖVEKEDÉSBEN
}

A magyar gazdaság növekedése regionális összevetésben rendkívül szerénynek bizonyult az elmúlt években. A szerzők több mint 4.500 vállalatot felölelő mintára építő kutatása szerint a vállalati növekedés lanyhulása mögött nem csupán a növekedési képesség, de a növekedési szándék mérséklődése is meghúzódik. Az utóbbi években inkább a hazai tulajdonú, 50 fő feletti, exportfókuszú cégek növekedtek, noha a gazdaságpolitika főként a külföldi kézben lévő cégek (FDI), a hazai KKV-k és a belső piac fejlesztését tűzte zászlajára. A GDP növekedési dinamikájának megemeléséhez a hazai szabályozási környezet stabilizálására, a gazdasági szereplők kilátásokba vetett bizalmának javítására, a központi centralizáció mérséklésére, a vállalati jövedelmezőség javítására lenne szükség.

Kulcsszavak: felzárkózás, tulajdon, export, Közép-Európa

A hazai gazdaság fejlődését elemezve igen eltérő hangokat hallunk manapság. Miközben a bruttó hazai össztermék (GDP) forintban mérve 2009 óta folyamatosan növekszik, euróban vagy dollárban mérve már koránt sem egyértelmü a sikertörténet. (1. táblázat) Regionális nemzetközi összevetésben vizsgálva az elmúlt éveket már kifejezetten kedvezőtlen kép rajzolódik ki. (1. ábra, 2. táblázat)

1. táblázat

A magyar GDP éves növekedési üteme

\begin{tabular}{|c|r|r|r|}
\hline & Ft & euró & dollár \\
\hline $\mathbf{2 0 0 0}$ & $14,47 \%$ & $11,28 \%$ & $-3,76 \%$ \\
\hline $\mathbf{2 0 0 1}$ & $15,49 \%$ & $17,00 \%$ & $13,77 \%$ \\
\hline $\mathbf{2 0 0 2}$ & $13,26 \%$ & $19,65 \%$ & $25,78 \%$ \\
\hline $\mathbf{2 0 0 3}$ & $9,51 \%$ & $4,96 \%$ & $25,89 \%$ \\
\hline $\mathbf{2 0 0 4}$ & $10,21 \%$ & $11,02 \%$ & $22,07 \%$ \\
\hline $\mathbf{2 0 0 5}$ & $6,88 \%$ & $8,45 \%$ & $8,47 \%$ \\
\hline $\mathbf{2 0 0 6}$ & $7,48 \%$ & $0,88 \%$ & $1,94 \%$ \\
\hline $\mathbf{2 0 0 7}$ & $5,80 \%$ & $11,25 \%$ & $21,15 \%$ \\
\hline $\mathbf{2 0 0 8}$ & $5,87 \%$ & $5,90 \%$ & $13,29 \%$ \\
\hline $\mathbf{2 0 0 9}$ & $-2,88 \%$ & $-13,03 \%$ & $-17,51 \%$ \\
\hline $\mathbf{2 0 1 0}$ & $3,02 \%$ & $4,95 \%$ & $0,11 \%$ \\
\hline $\mathbf{2 0 1 1}$ & $4,00 \%$ & $2,59 \%$ & $7,73 \%$ \\
\hline $\mathbf{2 0 1 2}$ & $1,76 \%$ & $-1,83 \%$ & $-9,27 \%$ \\
\hline $\mathbf{2 0 1 3}$ & $5,02 \%$ & $2,37 \%$ & $5,80 \%$ \\
\hline $\mathbf{2 0 1 4}$ & $7,03 \%$ & $2,96 \%$ & $2,97 \%$ \\
\hline
\end{tabular}

Forrás: KSH (2016a)

Az 1. ábrát, a 2. táblát és a mögöttük lévő adatsorokat elemezve igen heterogén fejlődési kép rajzolódik ki. A balti államok látványos fejlődése csak időlegesen tört meg a 2009-es válság hatására, lendületük töretlen. Bulgária és Románia igen hasonló utat bejárva ugyancsak képes folyamatosan a magyar fejlödésnél gyorsabb tempóra. Szlovákia és Lengyelország 2006 óta szakadt el a magyar fejlődési pályától, míg Horvátország és Csehország miénkhez hasonló dinamikát mutat, de eltérő relatív fejlettségi szinten.
1. ábra

Az egy főre jutó reál GDP alakulása a régióban (láncindex sor, euró, a 18 eurózóna-tag adott évi teljesítményének százalékában)

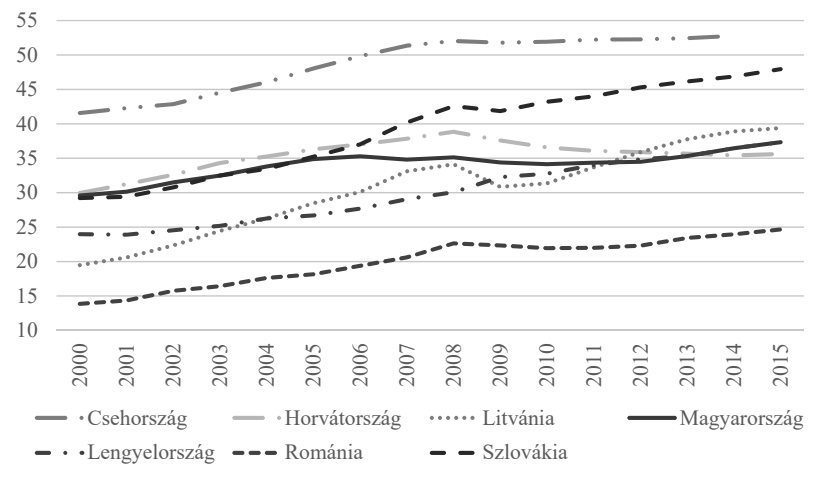

Forrás: KSH (2016b) alapján saját számítás

\section{2. táblázat}

Az egy före jutó reál GDP éves átlagos növekedése a régióban

\begin{tabular}{|l|c|c|}
\hline \multicolumn{1}{|c|}{ Ország } & $\mathbf{2 0 0 0 - 2 0 1 5}$ & $\mathbf{2 0 1 0 - 2 0 1 5}$ \\
\hline Litvánia & $5,43 \%$ & $5,02 \%$ \\
\hline Lettország & $4,99 \%$ & $4,91 \%$ \\
\hline Észtország & $3,85 \%$ & $4,03 \%$ \\
\hline Lengyelország & $3,61 \%$ & $3,01 \%$ \\
\hline Románia & $4,54 \%$ & $2,71 \%$ \\
\hline Szlovákia & $3,98 \%$ & $2,46 \%$ \\
\hline Bulgária & $4,37 \%$ & $2,25 \%$ \\
\hline Magyarország & $\mathbf{2 , 1 7 \%}$ & $\mathbf{2 , 1 5 \%}$ \\
\hline Macedónia** & $2,53 \%$ & $0,94 \%$ \\
\hline EU-28 & $0,93 \%$ & $0,70 \%$ \\
\hline Szerbia* & $3,48 \%$ & $0,60 \%$ \\
\hline Csehország* & $2,27 \%$ & $0,50 \%$ \\
\hline Ausztria & $0,85 \%$ & $0,45 \%$ \\
\hline Eurózóna (18 ország) & $0,60 \%$ & $0,35 \%$ \\
\hline Szlovénia & $1,69 \%$ & $0,34 \%$ \\
\hline Horvátország & $1,76 \%$ & $-0,19 \%$ \\
\hline \multicolumn{2}{|c|}{${ }^{* 2014-i g ~ * * 2013-i g ~}$} \\
\end{tabular}


A hosszú távú trendvonalak jól érzékelhetően elkülönülnek ezen országcsoportokban, felvetve a kérdést, miért nő a magyar gazdaság relatív és abszolút teljesítménye régiós összehasonlításban igen csak szerényen. A 2010 óta mutatott éves átlagos növekedést a 2000-ig visszatekintő idősorral összevetve kiderül: az utóbbi öt esztendőben mutatott teljesítményünk a volt szocialista országok közül csak Szerbia, Csehország, Szlovénia és Horvátország megelőzésére volt elég, 15 éves távlatban pedig pusztán a jóval fejlettebb Szlovéniát és Horvátországot tudtuk magunk mögé utasítani. Úgy látszik, hogy fejlődésben a régiós sereghajtók között állunk, s az utóbbi években sincsen nyoma igazi gyorsulásnak.

\section{A közelmúlt kutatási eredményei}

Kaitila (2014) az európai országok gazdasági konvergenciáját vizsgálta 1960 és 2012 között. Az EU-27 csoportban 1993 és 2000 közt csak igen szerény felzárkózás volt tetten érhetö, amelyet 2008-ig gyorsuló felzárkózás követett. Az ezt követő stagnálást 2011-2012-re váltotta csak fel némi gyorsulás. Így a rendszerváltó országok a 2000-es 41 százalékról 2012-re az EU-15-ök 60 százalékára tornázták fel magukat átlagosan. Ugyanakkor rámutat: Magyarország, Csehország és Románia felzárkózása a gazdasági válság kezdetétől más-más szinten ugyan, de egyformán megtorpant.

Eredményei alapján Európa gazdagabb országaiban kisebbek a jövedelemi egyenlötlenségek, mint a szegényebbekben. Azonban a várakozásoknak ellentmondva különös módon Cipruson, Litvániában, Magyarországon, valamint Lett-, Lengyel- és Csehországban a felzárkózás a jövedelmi egyenlőtlenségek növekedésével járt együtt.

Ez a hasonló mintázat azonban komoly különbségeket is rejt. Jasiński és Mielcarz (2013) azt elemezte, mi magyarázhatja, hogy szemben Spanyol- és Magyarországgal Lengyelországban a 2008-as válság nem hozott törést a gazdaság növekedésében. A siker, eredményeik szerint, a lengyel fogyasztók erősebb bizalmának, nagyobb költekezésének (szerényebb megtakarítási hajlandóságának), az alacsonyabb munkanélküliségi rátának és a könnyebb hitelhez jutásnak köszönhető. Kiemelik: Lengyelországban a másik két országnál egyébként átlagosan szegényebb lakosság fogyasztása a GDP több mint 60 százalékát teszi ki, felülmúlva a magyar és spanyol arányt, így a tartósan magas lakossági bizalmi index kulcsfontosságú volt a válság hatásainak tompításában.

Plaschinsky (2016) Lengyelország visegrádi országok közti növekedési előnyét magyarázva a prudens kormányzati politika fontosságára mutat rá. Kiemeli: Magyarországhoz képest az országának árfolyam-politikai mozgástere a külső eladósodottság jóval szerényebb mértéke miatt sokkal nagyobb volt a válság éveiben. Ráadásul a lengyel belső eladósodottság még nőni is tudott, nem fogva vissza a keresletet, miközben a szerényebb állami eladósodottság miatt a külső finanszírozási költségek is jóval enyhébben emelkedtek.

Balatoni és Pitz (2012) 1995 és 2010 között vizsgálva a magyar gazdaságot, rámutat: az átlagos 2,3 százalékos éves GDP-növekedésből 0,69-0,89 százalékos éves dinamika származott a külföldi müködő tőke beáramlásából. A külföldi érdekeltségü vállalatok a vizsgált 15 évben átlagosan a bruttó hozzáadott érték 20-25, a beruházások 27, míg a foglalkoztatás 15 százalékát adják. A külkereskedelmi áruforgalomban az export 65-70, míg az import 72-73 százaléka kapcsolódott e vállalatcsoporthoz.

Halpern és Oblath (2014) aláhúzza: Magyarországot a gazdasági stagnálás és az export bővülése egyszerre jellemezte az utóbbi években. Az 1995-2012 időszakot vizsgálva megállapítják, hogy miközben itthon a 2001-et követő lendület 2006 után kifulladt, az Csehországban kitartott a 2009-es válságig, Szlovákiában és Lengyelországban pedig a válság sem állította meg a felzárkózást. A szerzők a külső adósságszolgálat terheivel magyarázzák, hogy olyan korrekciókra volt szükség a válság nyomán, amely visszavetette a felzárkózást. E hatást csak fokozta a belső keresletet visszafogó prociklikus gazdaságpolitika és a lakossági adósságok leépítése. Mindez tökéletesen egybecseng Jasiński és Mielcarz (2013), illetve Plaschinsky (2016) bemutatott véleményével.

A kialakuló exporttöbblet - szerkezeti elemzésük szerint - a régióban egyedülálló módon úgy alakult ki, hogy az export növekedését az import visszaesése kísérte a válság után (Halpern - Oblath, 2014). Kiemelik: a hazai külgazdasági szektor reálteljesítménye európai összehasonlításban szokatlan mértékben távolodott el a gazdaság összteljesítményétől.

Ráadásul a magánszektor nettó beruházásainak százalékos növekedése a 2008-2012 időszakban mindvégig nálunk volt a legalacsonyabb a visegrádi országok között (Halpern - Oblath, 2014). Ez a kedvezőtlen trend pedig döntően hozzájárult a nettó exporttöbblet kialakulásához, amelyet viszont paradox módon előnyösnek szokás ítélni.

Kónya (2015) 1995 és 2013 között vizsgálta a hazai GDP-fejlődés szerkezetét, a tőkeállomány és a termelékenység oldaláról közelítve a problémát. Eredményei alapján a tőke hatása mindvégig jelentős volt: a teljes növekedésnek körülbelül 40 százaléka. A tőke 1995-től tartó folyamatosan gyorsuló növekedését azonban 2003-tól a növekedés stagnálása váltotta fel, majd 2008-tól kezdődően a tőke növekedési hozzájárulása rohamosan csökken. A termelékenységi faktor (TFP) 1997 és 2005 között játszott fontos szerepet, a munkainput súlya viszont csekélyebb volt, és csak az 1990-es évek második felében volt jelentős.

Elemzését áttekintve kiderül: a kapacitáskihasználtság visszaesése nemcsak a pénzügyi válság idején, 2008-ban és rekordmértékben 2009-ben rontotta a növekedést, de 2012-ben és 2013-ban is. Ráadásul a 2013-as negatív hatás mértéke még a 2008-as visszaesést is felülmúlta, ami aligha ösztönözte a cégeket további fejlesztésekre.

Báger (2015) a 2007-2013 időszakot elemezve azt hangsúlyozza, hogy a GDP 3,3 százalékos visszaesését Magyarországon az állóeszköz-beruházások 17,2 százalékos zuhanása kísérte. Rámutat: elsősorban az uniós támogatások bőségének köszönhető, hogy a visszaesés nem lett ennél is nagyobb.

Bayar (2015) a külföldön dolgozók által hazautalt jövedelmek és a közvetlen külföldi tőkebefektetések 
(FDI) 1996 és 2013 közötti szerepét vizsgálta rendszerváltó uniós gazdaságokban (Bulgáriában, Szlovéniában, Szlovákiában, Romániában, Cseh-, Horvát-, Lengyel- és Észtországban és Magyarországon). Eredményei szerint a külföldön dolgozók hazautalt jövedelmei a rákövetkező esztendőben okoznak GDP-bővülést, míg az FDI-beáramlás 2-3 éves késéssel eredményezi ugyanezt. Kimutatta: a vizsgált országokban a 2008-as csúcspontról a 2010-es mélypontig a külföldön dolgozók hazautalt jövedelme 33 százalékkal esett vissza, s ebből csak 10 százalékot sikerült visszanyerni 2013-ra.

Eftimoski, Josifovska és Josheski (2015) tizenkét közép- és kelet-európai országot az 1993-2011 időszakra vizsgálva kimutatta, hogy a régióban a munkavállalói jogok fokozottabb védelme magasabb foglalkoztatottságot és alacsonyabb munkanélküliségi rátát eredményezett. A demokratikus értékek erősödése szintén magasabb foglalkoztatottságot és több ledolgozott éves munkaórát eredményezett.

Érdekes módon ugyanakkor a Freedom House civil szervezet magasabb szabadságindexe rövid távon járt csak együtt csökkenő munkanélküliséggel, hosszabb távon viszont emelkedő ráta kísérte. A nagyobb kormányzati koncentráció azonban egyértelműen magasabb munkanélküliségi rátával járt, ahogy a GDP arányában mért állami költés emelkedése is növelte a hosszú távú munkanélküliséget.

\section{Tudnak és akarnak-e nőni a hazai cégek?}

A vállalatok növekedési lehetőségeire és szándékára számos belső vállalati és nemzeti makrogazdasági, politikai környezeti tényező hat. E mellett a globális világban egyre inkább szerepet játszanak a nemzetközi tényezők, olyan különbségek az egyes nemzeti gazdaságok jellemzői között, amelyek a vállalataik relatív pozícióját is befolyásolják.

A vállalatnövekedés lehetőségeit a piaci versenypozíciója, a termékeiben, a technológiájában megjelenő újdonság, innováció, a munkaerő és a menedzsment képessége, együttműködése és sok más belső erőforrás, tudás befolyásolja. Ezen túl lehetnek rövid távon ható növekedési tényezők, például a létező tartalékkapacitások, a tanulási hatás miatti termelékenységnövekedés, szerencse a divathullámok kihasználásakor, a versenytársak hibái, gyengeségei és sok más tényező. Így egy-egy vállalat teljesítménye, növekedése sok hosszabb, vagy rövidebb távon ható tényezőnek az eredménye. Ez megjelenik a vállalati különbségekben, így az eltérö növekedési lehetőségekben is.

A növekedésnek a forráslehetőségek és a hozamelvárások miatt vannak pénzügyi korlátai is. Rövidebb távon egy-egy cég akár külső erőforrásokat: új tulajdonosi tőkét vagy visszafizetési kötelezettséggel terhelt forrásokat is bevonhat tevékenysége finanszírozásához. Hosszabb távon azonban csak olyan növekedés képzelhetö el, amely önfinanszírozó, vagyis a felvett hitel törleszthető és még marad kellö tulajdonosi jövedelem is. Ha a hozam tartósan meghaladja a kockázattal arányos hozamelvárást, akkor a befektetési, beruházási javaslatot a döntéshozók támogatni fogják. Vállalati szintü döntés nyomán tehát a növekedés lehet nulla, vagy akár negatív is, ha a jövőbeni kilátások miatt a tőkekivonás a racionális tett.

A hozamelvárások teljesíthetősége függ a vállalattól, de függ attól a társadalmi közmegegyezéstől is, amely alapján a jövedelmek megosztása kialakul. A vállalat által realizált jövedelem maradványként jelentkezik, s mértékében jelentős különbségek vannak az egyes országok között. A demokráciákban a különböző országok a jövedelem megosztását a saját közmegegyezésük, értékrendjük alapján igen eltérő arányokkal valósítják meg. A költségvetési centralizációban akár 20-30 százalékos eltérések is kialakulhatnak a különböző országok között (Muraközy, 2015).

A vállalati szektor nagymértékben meghatározza a megtermelt jövedelem (GDP) tömegét, s ebben tükröződik a termelékenységi, nemzetközi pozíciója. A jövedelem megosztása azonban gazdaságpolitikai kategória. Az egész vállalati szektor növekedése módosul, ha a 100 egységnyi GDP-ből 10 helyett 15 egység marad a cégeknél, hiszen ennek megfelelően változik a befektetői jövedelmezőség is. Hosszú távon a költségvetési bevételek által indukált adózási, bérszabályozási (minimálbér) döntés hatása a vállalati jövedelmekben, a maradványban csapódik le. Így egy-egy adózási, gazdaságpolitikai döntés után a vállalat kényszerül alkalmazkodásra, s ez érinti a növekedést is.

Zárt gazdaságban ez a jövedelemmegosztás nem rendezi át a versenypozíciókat, hatása az alacsonyabb növekedési potenciálban jelenik meg. A nemzetközi kereskedelem korábbi szakaszában, amíg a piacon döntően a magasabb centralizáltságot mutató államok versenyeztek egymással, addig a magas, de egymáshoz közel eső centralizáció nem rendezte át alapvetően a versenypozíciókat.

Ma a globális világban a közszféra kiterjedtsége, az abban megfigyelhető jókora eltérések sokkal inkább hatnak a növekedési lehetöségekre. Afonso és társai (2006) nem találtak ugyan egyértelmü bizonyítékot arra, hogy a magas centralizáció visszahat az adott országok növekedésére, de eredményeik alapján inkább valószínűsíteni lehet ennek az összefüggésnek a fennállását, hiszen a vizsgált körben negatív $(-0,56)$ volt a korreláció a növekvő költségvetés és a gazdasági növekedés között, amikor a korrelációt a 30 százalék fölötti költségvetési kiadással rendelkező országok körében vizsgálják. Ez erősíti a szerzőknek azt a feltételezését, hogy a növekedés szempontjából a költségvetés alacsonyabb - véleményük szerint 35 százalék körüli - aránya az optimális.

A centralizáció és a vállalati jövedelmezőség közti kapcsolatot az OECD (2016) adataira támaszkodva az OECD országaira mi is ellenőriztük. (2. ábra) Az adatbázisban 18 ország adatai voltak elérhetők. Eredményeink szerint a két változó közti kapcsolat közepesen erős és negatív (korrelációs együttható: - 0,5035), az eszközarányos jövedelmezőségben fellelhető variancia 25 százaléka megmagyarázható az állami elvonások GDP-arányos mértékével. Minden más tényező változatlansága mellett az állami centralizáció egy százalékkal való emelése 0,44 százalékkal csökkenti a vállalatok befektetett eszközarányos jövedelmezőségét, ami döntően kihat a cégek és így 
az adott ország GDP-jének növekedésére is. A modell részletes eredményeit a 3. táblázat mutatja.

2. ábra

\section{A Nettó működési eredmény/Befektetett eszközök és az Adóbevétel/GDP-mutatók kapcsolata az OECD-országokban (2012)}

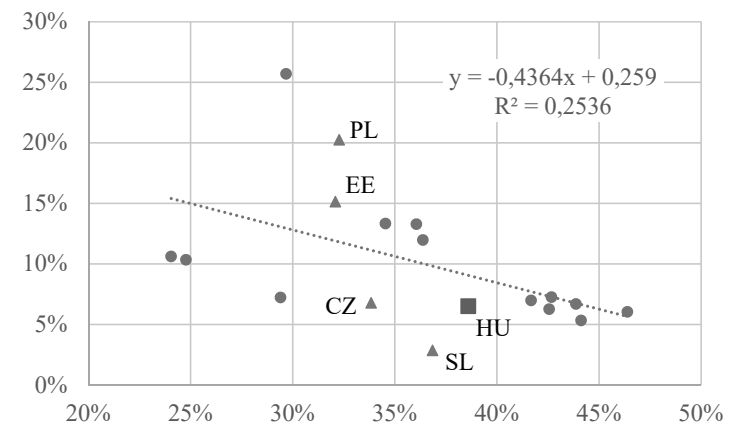

Forrás: saját számítás OECD (2016a és 2016b) adatok alapján

3. táblázat

A regressziós modell eredményei

\begin{tabular}{lrrccr}
\hline & $d f$ & \multicolumn{1}{c}{$S S$} & $M S$ & $F$ & Szignif. \\
\hline Regresszió & 1 & 0,0143 & 0,0143 & 5,4355 & 0,0331 \\
Maradék & 16 & 0,0421 & 0,0026 & & \\
Összesen & 17 & 0,0564 & & & \\
\hline & $\begin{array}{l}\text { Koeffi- } \\
\text { ciensek }\end{array}$ & $\begin{array}{l}\text { Stan- } \\
\text { dard } \\
\text { hiba }\end{array}$ & térték & p-érték & \\
\hline $\begin{array}{l}\text { Tengely- } \\
\text { metszet }\end{array}$ & 0,2590 & 0,0687 & 3,7727 & 0,0017 & \\
X változó 1 & $-0,4364$ & 0,1872 & $-2,3314$ & 0,0331 & \\
\hline
\end{tabular}

Éppen ezért minden országnak mérlegelnie kell a növekedési lehetőségek és költségvetés mérete közötti összefüggést. Ezt tette De Witte és Moesen (2010), akik a GDP növekedése szempontjából már a 2007-es adatok alapján is az állam visszahúzódását tartották szükségesnek az OECD-országok többségében. Véleményük szerint a jövedelmek elosztásának az újragondolása szükségszerüség, de ez Európában a globális versenyképesség megtartása, visszaszerzése miatt alapvető érdek is.

Magyarország 2010 után a válságból történő kilábalásnak azt az útját választotta, amely igyekszik elkerülni a lakossági megszorításokat. Így a válságkezelés döntő részben vállalati pluszterhekkel párosult. Ezek a pluszterhek nem minden esetben voltak hatásukban egységesek: részben differenciáltan érintettek különböző ágazatokat és/vagy a különböző (méretü) társaságokat. Nem csökkent a GDP centralizációja, nem növekedett, sőt inkább csökkent az a maradványjövedelem, amely a GDP-ből a cégeknél maradt. A maradványjövedelem mérséklődött a hazai kereslet 2009-ben bekövetkezett drasztikus visszaesése és a GDP csökkenése miatt is. Ez tükröződik a hazai vállalati beruházások volumenében, s egyben a hazai GDP növekedési ütemében is.

Éppen ezért indokolt annak a kérdésnek a felvetése, hogy miként alakultak a hazai vállalatok növekedési lehetőségei és szándékai a válság után. Milyen volt a vállalatok jövedelemszintje, elérték-e a beruházáshoz szükséges jövedelmezőségi küszöbértéket? Hogyan oszlanak meg a vállalatok a növekedési lehetőségek szempontjából? Mennyiben éltek a lehetőségekkel, hogyan alakultak a megtermelt jövedelem felhasználására vonatkozó döntéseik? Sikerült-e növekedési pályára állniuk?

Ezeket a kérdéseket vizsgáljuk a következökben. Feltételezzük azt, hogy a vállalat belső és nemzetközi pozíciója, valamint a nemzeti környezeti feltételek egyaránt befolyásolják teljesítményüket, valamint döntéseiket. Ugyanakkor nem tudjuk szétválasztani azt, hogy a vállalati döntésekben milyen mértékben játszottak szerepet az egyedi vállalati jellemzők, a piaci potenciál, versenyképesség, vállalati teljesítmény, illetve a gazdasági, politikai környezet, a jövedelem centralizációja. A cégeket vizsgálva ezek eredőjét tudjuk mérni, a hatótényezőkre csak feltételezéseket, esetleg logikai úton alkotott következtetéseket adhatunk.

\section{A vállalati minta jellemzői és a vizsgálat módszere}

A piaci verseny még a csak mérsékelten hatékony piacon is a vállalatok szelekcióját eredményezi, ami az eltérő növekedési lehetőségben is megjelenik. Az alacsony jövedelmezőség korlátozza, a kiemelkedő profitabilitás viszont serkenti és képessé is teszi a társaságokat a gyorsabb növekedésre. Egyébként változatlan feltételek mellett a magasabb vállalati jövedelem tendenciaszerüen magasabb beruházást, magasabb növekedési potenciált eredményez, míg az elégtelen jövedelem még a pótlás elmaradásával vagy halasztásával jár.

A szelekció miatt a növekedési potenciál vállalatonként vizsgálható, s ennek során kulcskérdés a cégek jövedelmezőség szerinti megoszlása. A ténylegesen növekvő vállalatok körét elsősorban az jelöli ki, hogy mennyien vannak a kritikus hozamszint alatt. Éppen ezért vizsgálatunkban a jövedelmezőségi információt hordozó egyedi vállalati pénzügyi kimutatásokból indultunk ki.

Azt feltételeztük, hogy a növekedési lehetőségeket döntően a cég alapvető gazdasági jellemzői (fundamentumai) határozzák meg. Ilyen tényező például a piaci részesedés vagy a kialakult árak és a vevőkapcsolatok. Ezekben egyik napról a másikra drasztikus változást nem lehet vagy nagyon nehéz elérni. Ugyancsak ilyen a vállalat technikai bázisa, termelöképessége, vagy a dolgozók, vagy a menedzsment tudása, képességei is. Ezek hosszú idő alatt épülnek ki és csak hosszabb idő alatt változnak. Természetesen mód van ezek átalakítására is, de ezekre úgy tekintünk mint potenciális növekedési többletekre.

Ugyanakkor a növekedési lehetőség nem azonos a növekedési szándékkal. A növekedésre vonatkozó döntéseket a gazdasági környezet kockázatának megítélése is befolyásolja. Az elmúlt évek gazdasági válsága okozta 
sokkszerű változás átrendez(het)te a hozamelvárásokat és a vállalati pozíciókat. Ez egyes cégeknél lehetőségeket teremthetett, másoknál a pozíció romlását, akár a visszafejlesztés kényszerét is magával hozhatta. Éppen ezért öt év, a 2010-2014 időszak pénzügyi kimutatásait használtuk fel, így mód lehet a 2010 és a 2014 közötti átrendeződések megragadására is.

A tőkéhez kapcsolódó transzferek, az osztalék, a tőkekivonás, illetve a pótlólagos tőkeemelés befolyásolják a növekedéshez rendelkezésre álló forrásokat. Az ilyen döntések meghozatalához sok tényezőt kell mérlegelni. A gazdasági, politikai környezet, a régió, az ország relatív pozíciója, a politikai stabilitás és a kiszámíthatóság ezekben lényeges szerepet játszik. Éppen ezért fontos, menynyire elkötelezettek a társaságok a folytatás, a megtermelt jövedelmet újra befektető normál növekedési pálya mellett, mennyiben vállalnak dinamikus (tőkét bevonó) fejlesztéseket, mennyiben döntenek a tökekivonás, az összehúzódás mellett. Vizsgálni kell, hogy mennyiben tér el a növekedési lehetőség és a szándék egymástól.

Ha egy kevésbé fejlett, vagy feltörekvő gazdaságban, ahol nem homogén (például duális) a vállalati szerkezet, a vállalatok teljesítménye és a növekedés lehetősége is eltérő. Ezért az átlagokra építő makroszintű elemzések nem alkalmasak a problémák, az anomáliák feltárására.

Magyarországon kettős dualitás áll fenn (részletesen lásd: Reszegi - Juhász, 2014). A vállalatok közötti teljesítménykülönbségek szignifikánsan különböznek a külföldi tulajdonú cégeken belül is a munka(bér) színvonala alapján, és a hazai cégeken belül az intenzíven exportálók javára. Egyrészt a teljesítményszintek szignifikánsan eltérnek a cégek között, másrészt más a külpiaci integráltságuk mértéke is. Emiatt indokolt a növekedési lehetőségek különbségeit a tulajdonosi háttér, illetve az exportorientáltság alapján is megvizsgálni.

\section{A vizsgálat modellje}

A növekedési lehetőségeket pénzügyi oldalról, a finanszírozhatóság szempontjából közelítjük. Elsődleges vizsgálati kérdésünk az, hogy legfeljebb mekkora növekedést tud egy adott vállalat elérni akkor, ha a hatékonysága, teljesítménymutatói és a finanszírozási struktúrája nem változik. Ezt fenntartható fejlődési pályának is nevezik (Higgins, 2012, 4. fejezet).

A közelítésünk azt feltételezi, hogy a vállalat folytatja eddigi tevékenységét, és fenntartható fejlődési pályán halad. Követi a lehetőségeit, fejleszti termelési kapacitását, eszközeit. A modellünk a következő négy feltevésre épül.

(1) A vállalat tőkestruktúrája, azaz az idegen tőke (D) és a saját tőke (E) aránya állandó: a bővítését, növekedését ugyanolyan arányban finanszírozza saját tőkéből és adósságból, mint eddig. Ebből következően a befektetett tőke $(\mathrm{D}+\mathrm{E}=\mathrm{IC})$ növekedésénél a saját tőke bővülése az egyik korlát, hiszen ez szabja meg a hitelek növekedési ütemét is. Feltételezzük, hogy a tulajdonosok a kockázatviselö hajlandóságuk alapján jól döntöttek a D és az E arányának kialakításában, s azt továbbra is fenn lehet tartani. Az idegen és saját tőke piaci és könyv szerinti értéke közt nem teszünk különbséget.

(2) A vállalat müködésének jellemzői változatlanok, továbbra is ugyanolyan technikai felszereltséggel, ugyanolyan tőke-munka kombinációval, ugyanolyan tőkeforgással (Árbevétel/Befektetett tőke) müködik. Tehát sem a termék vagy a termékstruktúra, sem a tényezőárak arányai nem változnak.

(3) Nincsenek kapacitástartalékok, tehát a növekedéshez bővíteni kell az eszközöket. A növekedéshez beruházás és pótlólagos müködő tőke biztosítása szükséges, mivel a hatékonyság, a teljesítmény nem változik.

(4) Ha a vállalat veszteséges, akkor a növekedési lehetősége nulla, hiszen nem fenntartható pályán van. A túléléshez a pálya, a stratégia módosítása szükséges, vagy a cég a szelekció áldozata lesz.

Ezt a növekedési pályát nevezi Higgins (2012, 4. fejezet) fenntartható növekedési pályának. Az általa meghatározott fenntartható növekedési ütem (g) függ az adó utáni eredménytől (NI), az eszközök körforgásától, a visszatartott nyereségtől - amelyet az osztalékfizetési hányad (DIV/NI) határoz meg -, valamint a tőkeáttételtől (IC/E).

$$
\frac{\mathrm{NI}}{\text { Árbevétel }} * \frac{\text { Árbevétel }}{\mathrm{IC}} * \frac{\mathrm{IC}}{\mathrm{E}} * \frac{\mathrm{NI}-\mathrm{Div}}{\mathrm{NI}}=\mathrm{g}
$$

A következőkben mintánk jobb elemezhetősége érdekében e modell módosított változatát használjuk, a hazai pénzügyi kimutatások szerkezetéhez igazítva azt. E modellben a kritikus növekedési tényező a saját tőke bővülési üteme. Ha a tőkestruktúra és a tőkeforgás állandó, a teljes adózott eredmény visszaforgatásakor a $\mathrm{g}=\mathrm{NI} / \mathrm{E}=\mathrm{ROE}$, ami a fenti képlet egyszerüsítéséből is kimutatható, ha az osztalék (Div) nulla.

A növekedést a modellünkben a ROE határozza meg, amelyet a saját tőke könyv szerinti értéke (E) alapján határozunk meg. Mivel a saját tőke piaci értéke rendszerint a könyv szerinti érték fölött van, a könyv szerinti számított ROE csak akkor becsülné túl a növekedési lehetőséget, ha a vállalat piaci értéke alacsonyabb, mint tőkéjének könyv szerinti értéke. Ez viszont csak elégtelen (az elvárttól elmaradó) teljesítménynél lehetséges. Ilyen esetben a forrásbiztosítók, a tulajdonosok és a hitelezők is racionális döntést hoznak, nem biztosítanak forrásokat elégtelen várható hozamok mellett. Jól müködő társaságoknál tehát a ROE biztosan felső becslése a növekedési lehetőségeknek.

A vállalat legfontosabb fundamentális jellemzője, hogy adott árbevétel mellett milyen müködési, kamat és adó előtti eredményt (Earnings Before Interest and Tax - EBIT) ér el. Így az eredményesség egyik legfontosabb leírója az EBIT/Árbevétel, vagyis a működési eredményhányad (operating profit margin). Az alkalmazott feltételek mellett ez az eredményhányad határozza meg a növekedés felső határát a tőke, a források oldaláról. (A számviteli elszámolásokban ezek után már csak a finanszírozási és a rendkívüli tételek következnek. Ez utóbbiak csak egyedi esetekben, adott évben módosíthatnak, hoszszabb távon azonban csak az alaptevékenységgel indokolt számolni.) 


$$
\frac{\text { Árbevétel }}{\mathrm{IC}} * \frac{\mathrm{EBIT}}{\text { Árbevétel }}=\mathrm{ROI}=\mathrm{g}^{*}
$$

A g* növekedési ütem akkor valósítható meg, ha nincsenek adók és nincsenek terhei (kamat) a tőkének (például hitelmentes a müködés, azaz $\mathrm{IC}=\mathrm{E}$ ). Adók hiányában változatlan teljesítmény és hitelmentes finanszírozás mellett, osztalék nélkül az árbevétel, az EBIT és a saját tőke (E) növekedése is azonos $(\mathrm{g} *=\mathrm{ROI}=\mathrm{ROE})$. Ha adókkal is számolunk, akkor a fenntartható növekedési lehetőség szükségszerüen csökken $\left(g^{*}>g^{\prime}\right)$.

$$
\frac{\text { Árbevétel }}{\mathrm{IC}} * \frac{\mathrm{EBIT}}{\text { Árbevétel }} * \frac{\mathrm{EBIT}^{*}(1-\mathrm{t})}{\mathrm{EBIT}}=\mathrm{ROI}=\mathrm{g}^{\prime}
$$

A g' nemcsak a feltételeink szerint elérhető növekedési ütem, hanem a befektetett tőke megtérülését is mutatja. Az r hozam kitüntetett jelentőséggel bír, hisz a vállalatnak a tőkeköltségét (r*) a piac határozza meg, annak hasonló kockázatú alternatív befektetések hozamát el kell érnie. A tőkeköltség (elvárt hozam) r* függ a cég specifikus kockázatától, a kockázatmentes hozamok nagyságától és a tőkepiaci hozamoktól és a tőkeáttételtől (Lásd erről Brealey - Myers, 2005).

$$
\frac{\operatorname{EBIT}^{*}(1-\mathrm{t})}{\mathrm{IC}}=\mathrm{ROI}=\mathrm{r}
$$

A vállalati cél az, hogy az $r$ az r*-nál nagyobb legyen, mert ilyenkor a befektetett tökéhez képest többletérték keletkezik. Ez az alapja a növekedési stratégiának: ha a vállalat nem tud többletértéket teremteni, akkor nem vállal pótlólagos befektetést és érdemes a szabad pénzeszközöket kivonni a vállalatból.

Azt, hogy egy-egy vállalat esetében az r* mekkora, a pénzügyi kimutatások alapján nem állapítható meg. Ugyanakkor bizonyos, hogy annak értéke meghaladja az idegen források költségét, azok elvárt hozama pedig biztosan felette van a visszafizetési kockázattól mentes állampapír-hozamoknak. Ezért az adott időszak állampapír-hozamai adhatnak némi tájékozódási pontot.

A növekedési lehetőségeket mindenképpen befolyásolja az osztalék, a tőkeemelés és a tőkekivonás. Ezzel a számításoknál vállalatonként módosítottuk az értékét, az így kapott $g$ már a szándékolt növekedést fejezi ki a korábban jelzett feltételrendszerünkben.

A kapott képhez hozzátartozik az, hogy a növekedési lehetőséget csak pozitív saját tőke esetén érdemes becsülni, ezért ki kell hagyni az elemzésből a negatív saját tőkéjü cégeket, azoknál egyéként is nehéz fenntartható müködésröl beszélni. Az is árnyalja a képet, hogy nem számolunk azzal, hogy a növekedési lehetőség egy-egy új termékkel, innovációval, termelékenységemelkedést hozó szervezéssel, új stratégiával javulhat, el lehet érni a korábbinál jobb hozamokat. Így a növekedési lehetőség egyrészt kisebb, másrészt nagyobb is lehet a fundamentumok alapján kimutatottaknál.

\section{A vállalati minta legfontosabb jellemzői}

Vállalati mintánkba olyan nem pénzügyi tevékenységet végző magánvállalkozások kerültek be, amelyek 2013-ban legalább 20 föt foglalkoztattak és minden vizsgált évre teljes (nem egyszerüsített) pénzügyi kimutatást készítettek. Kihagytuk az állami tulajdonban lévő és a legalább egy évben negatív saját tőkével müködő társaságokat is.

Ugyancsak kikerültek azok a cégek, amelyek a vizsgált 2010-2014 időszakban átalakultak, vagyis szétváltak vagy egyesültek, esetleg a felszámolás, vagy a végelszámolás sorsára jutottak. Mintánk tehát nem reprezentatív a teljes gazdaságra nézve, mivel csak a versenyszektor élvonalát tartalmazza, amelyet a folytonosan müködő, átlagnál nagyobb méretű (egyszerüsítet kimutatás benyújtására nem jogosult) és pozitív tőkéjü, vagyis tartósan eredményes cégek jelenléte biztosít.

\section{4. táblázat}

A minta súlya a nem pénzügyi vállalatok makroadataihoz viszonyítva (2013)

\begin{tabular}{|l|r|r|r|}
\hline & $\begin{array}{r}\text { Nemzetgazd. } \\
\text { nem pü. váll. }\end{array}$ & $\begin{array}{c}\text { Minta * } \\
\text { 4166 vállalat }\end{array}$ & $\begin{array}{c}\text { Minta/ } \\
\text { nemzetg. (\%) }\end{array}$ \\
\hline $\begin{array}{l}\text { GDP hozzájárulás 1. } \\
\text { (KSH, MFt) }\end{array}$ & 15747465 & 8567118 & 54,4 \\
\hline $\begin{array}{l}\text { GDP hozzájárulás 2. } \\
\text { (KSH, MFt) }\end{array}$ & 15747465 & 6186173 & 39,3 \\
\hline $\begin{array}{l}\text { Állóeszközök } \\
\text { (KSH, MFt) }\end{array}$ & 48146000 & 12223733 & 25,4 \\
\hline $\begin{array}{l}\text { Létszám a verseny- } \\
\text { szférában (KSH, fó) }\end{array}$ & 1819100 & 703500 & 38,7 \\
\hline $\begin{array}{l}\text { Külföldiek bef. } \\
\text { tőkéje (KSH, MFt) }\end{array}$ & 18572900 & 9748582 & 52,5 \\
\hline $\begin{array}{l}\text { Amortizáció (KSH, } \\
\text { MFt) }\end{array}$ & 3772271 & 1347789 & 35,7 \\
\hline $\begin{array}{l}\text { Nettó múk. ered- } \\
\text { mény (KSH, MFt) }\end{array}$ & 4238601 & 1476193 & 34,8 \\
\hline $\begin{array}{l}\text { Társasági adóbefi- } \\
\text { zetés (KSH, MFt) }\end{array}$ & 301553 & 131757 & 43,7 \\
\hline $\begin{array}{l}\text { Export (KSH, teljes } \\
\text { gazd, M euró) }\end{array}$ & 89064 & 58167 & 65,3 \\
\hline $\begin{array}{l}\text { Bruttó hozzáadott } \\
\text { é./ Bruttó kibocsátás } \\
\% \text { (OECD: } 38,9)\end{array}$ & 13,0 & 12,1 & 186,2 \\
\hline $\begin{array}{l}\text { Bruttó múk. } \\
\text { eredmény/ } \\
\text { Állóeszközök \% } \\
\text { (OECD: } 18,5)\end{array}$ & 6,5 & 32,0 & 92,5 \\
\hline $\begin{array}{l}\text { Nettó múk. ered- } \\
\text { mény/ állóeszköz \% } \\
\text { (OECD: } 10,1)\end{array}$ & 34,6 & 176,9 \\
\hline
\end{tabular}

*OECD (2014 és 2016a) és KSH (2016c és d) adatok. A vállalati adatok a 2013as pénzügyi kimutatásokból származnak, amelyek nem teljesen kompatibilisek a makroszámvitellel, a GDP-hozzájárulásban 39,6 és 54,9 százalék között van a tényleges súlya a mintának (zárójelben az adatok forrása).

A Bisnode adatszolgáltató cégtől kapott adatbázisunkban rendelkezésre állnak a hivatalos létszámadatok is minden egyes évre. A cégnyilvántartási adatok alapján ismert a 
minta vállalatainak a végső tulajdonosa is, így a 4.166 vállalatból 2.597 többségi magyar tulajdonban van, míg 1.569 többségi külföldi tulajdonú (a megismerhetetlen hátterű, offshore tulajdonosú cégeket töröltük). Így mód van arra, hogy a tulajdonosi háttér alapján is vizsgáljuk az eltéréseket.

A minta jelentőségét, gazdasági súlyát (4. táblázat) az adatok alátámasztják. A vizsgált vállalatok befektetett tőkében, GDP-hozzájárulásban és exportban is kiemelkedő részesedéssel rendelkeznek. Külön ki kell emelni a bruttó és nettó müködési eredmény/állóeszköz mutatókat, amelyekben a magyar gazdaság egésze jelentősen le van maradva az OECD-átlaghoz képest, de mintánk mind a magyar átlagot, mind az OECD-átlagot jelentősen felülmúlja.

A minta a tőke szerkezetében, a D s az E arányában nem mutatott érdemi változást 2010 és 2014 között. Miközben az IC, (D+E) 12,7 százalékkal, vagyis az inflációs érték alatt nőtt, addig a finanszírozási szerkezetnél a saját tőke aránya lényegében nem változott, 74,1-ről 74 százalékra csökkent. Így a modellünk feltételei közül a legfontosabb a tőkeszerkezet állandósága lényegében teljesült. Gyakorlatilag nem változott érdemben a technikai felszereltség sem, ha azt egy före jutó tárgyi eszköz állományban mérjük, az szintén infláció (19,96 százalék) alatt, 11,1\%-kal nött, de ez az eszközök hosszabb amortizációja miatt természetes is lehet. Ugyanakkor a technikai felszereltségben a szórás csökkent, így nem valószínűsíthető alapvető, a növekedési lehetőségeket lényegesen befolyásoló hatás a használt eszközök, gépek oldaláról. A cégek árbevétele összességében 23,3 százalékkal nőtt folyó áron, s ez nem zárja azt ki, hogy 2010ben voltak kapacitástartalékok, hisz az árbevétel kétszer akkora mértékben nőtt, mint a működést szolgáló tőke (IC). Ez azonban inkább pozitív irányba befolyásolja a növekedési lehetőségeket, mintsem mérsékelné. Összességében a müködési jellemzők tehát nem változtak úgy, hogy azok a növekedési lehetőségek elemzését, modellünk alkalmazhatóságát, vagy a kapott eredmények relevanciáját mérsékelné.

Egy országban a gazdasági növekedést alapvetően a nagyobb, sikeres vállalatoktól lehet várni. Mintánk ugyan statisztikailag nem reprezentatív, de minden vállalat benne van, amelyik a korábban jelzett feltételeknek megfelel. A minta alapvetően a jobb, stabilan müködő vállalatokat tartalmazza. A minta nagysága, a foglalkoztatásban, a külföldi befektetésekben és az exportban elfoglalt súlya megengedi azt a következtetést, hogy e vállalati körnek a magatartása döntően hat a magyar gazdaság teljesítményére. Mintánk inkább felülbecsüli a növekedési lehetőségeket, mivel nehéz elképzelni azt, hogy az alacsonyabb hatékonyságú kisebb, a veszteséges vagy az állami tulajdonú vállalatok inkább rendelkeznek növekedési potenciállal. Így a magyar gazdaság növekedését leginkább ez a vállalati kör határozza meg. Ha e körben elégtelen a növekedési potenciál vagy a szándék, akkor az az országban a GDP növekedését is mérsékli, azt csak a pénzügyi vállalatoknak vagy a kormányzati, az állami szektornak a nagyobb növekedése ellensúlyozhatná.

\section{Az elemzés legfontosabb eredményei}

Az elemzés során külön vizsgáltuk a ROI, a ROE, az osztalék utáni mérleg szerinti eredménynek (MSZE) és a tőkeemelések és -kivonások utáni saját tőkeváltozást (+/-Tőke+MSZE). Ezeknek a mutatóknak az értéke feltételeink között kifejezi a saját tőke növekedését, amely a forrása lehet a fenntartható, azonos tőkestruktúra mellett bekövetkező növekedésnek.

A növekedési potenciált alapvetően a vállalat teljesítménye, az EBIT/IC határozza meg. A tényleges növekedési potenciált módosítja a profitadó. A hazai gyakorlatban azonban az EBIT értékét is befolyásolják adók, illetékek, egyéb kormányzati és önkormányzati terhek. A pénzügyi kimutatásokból azok a „láthatatlan adók”, terhek, amelyeket már az üzemi eredmény (EBIT) előtt elszámolnak, nem határozhatók meg. Magyarországon ilyen az iparüzési adó vagy az ingatlanadó, de számos más, kisebb adó, a tranzakciós illeték, a kötelező kamarai tagdíj és az innovációs járulék is. Egyes ágazatokban a különadóval is kiegészülve, ezek összességükben többszörösen, akár nagyságrendileg is felülmúlják a profitadót. Így a ROI a kimutatások sajátosságai miatt adóval részben már csökkentett növekedési lehetőséget jelent.

A mérleg szerinti eredmény, illetve a tőkeemelések, kivonások utáni saját tőkeváltozás és a ROE eltérése nem a lehetőségekről, hanem inkább a növekedési szándékokról szól. Kifejezetten a tulajdonosi döntések miatt mutatkozik eltérés a megtermelt tulajdonosi hozamot kifejező ROE és a tényleges tulajdonosi tőkeváltozás között.

Azt, hogy a szándékokat milyen tényezők mozgatják, a pénzügyi kimutatásokból nem lehet megítélni. Lehetnek gazdasági, ágazati vagy specifikus vállalati okai is, de a döntés szólhat a hazai szabályozási környezetről, valamint a gazdaságpolitikába vetett bizalomról is. A teljesítmények és az elvárható racionális magatartás összevetése alapján csak becsléseket adhatunk a mozgató rugókra. A 3. ábra a vállalatok növekedésének eloszlását mutatja a legfontosabb növekedést meghatározó mutatók alapján azon cégekre, amelyek mutatóértéke a -100 százalék és a +100 százalék közötti sávba esett.

3. ábra

A (Tőkeemelés+Mérleg szerinti eredmény)/Saját tőke mutató mintabeli eloszlása (2014)

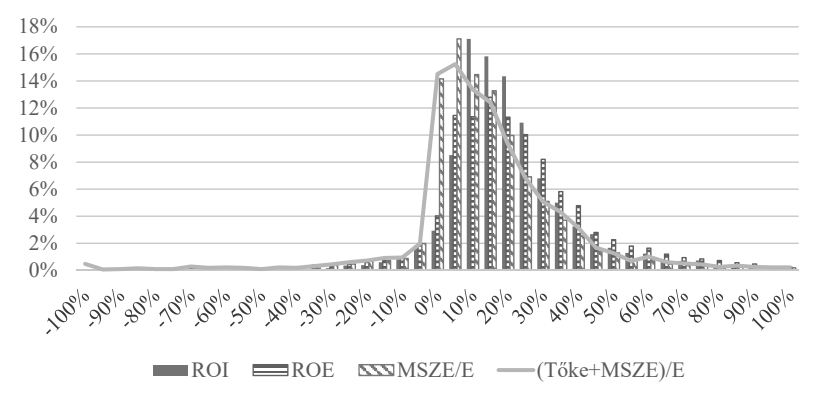

A növekedés szempontjából van egy kritikus hozamszint, amely alatt nem, vagy csak igen jelentős teljesítménynövekedés alapján célszerű növekedni. Ez a szint az adott 
időszakban saját tanácsadási és kutatási tapasztalataink szerint legalább 10 százalék lehetett.

A vállalatok eloszlását az 5 százalékos szintre is megadjuk. Ennek oka az, hogy 2010-2014 között a hozamelvárásra alsó becslést adó, visszafizetési kockázattól mentes állampapírok hozama nagyjából ezen a szinten állt. Így szinte biztos, hogy az ezt az értéket el nem érő cégek értékrombolók voltak, ha számvitelileg nem is veszítettek vagyonukból.

5. táblázat

\section{A cégek jövedelmezőség szerinti megoszlása 2014 (\%)}

\begin{tabular}{|l|c|c|}
\hline & $\begin{array}{c}10 \% \text { alatti cégek } \\
\text { aránya }\end{array}$ & $\begin{array}{c}5 \% \text { alatti cégek } \\
\text { aránya }\end{array}$ \\
\hline ROI & 33,6 & 16,5 \\
\hline ROE & 33,4 & 22,1 \\
\hline MSZE/E & 52,2 & 37,7 \\
\hline (+/-Tőke+MSZE)/E & 51,4 & 38,1 \\
\hline
\end{tabular}

A kép igen differenciált (5. táblázat). A ROI és a ROE sorainak eltérése kifejezi a társasági adó miatti növekedési potenciálveszteséget, valamint a tőkeáttétel pozitív növekedési hatását is. Ha valamennyi vállalati közteher teljes nagyságát ismernénk, a két sor még inkább eltérne, mutatva ezzel az újraelosztás növekedési potenciált csökkentő hatását.

A növekedési képesség azonban még tovább csökken, amikor a mérleg szerinti és a tőkeváltozásokkal korrigált mutatót vizsgáljuk. Ez mindenütt, még a 30-40 százalékos megtérülést mutató cégeknél is (!), a növekedési szándék csökkentését jelzi. Nincs vagy kevés a tökeemelés, viszont van tőkekivonás akár osztalék, akár tőkeleszállítás formájában. Az erőteljesebb növekedési szándékot tehát kevesebb, mint a cégek felénél lehet feltételezni.

Önmagában a teljesítmények alapján (ROE és ROI) csak a cégek egyharmada az, amelynek hozama mellett már igencsak megfontolandó a további befektetés vagy a tőke megtartása. Mégis a cégek több mint fele kevesebb pénzt hagy bent a cégben, vagyis közel húsz százalék a kritikus szint feletti jövedelmet termel, de azt kiveszi, esetleg még tőkét is leszállít.

Az 5 százalék alatti ROE-t a cégek ötöde éri el, viszont a társaságok 38,1 százalékánál 5 százalék alatti a tőke változása az osztalék, a tőkeemelés és tőkecsökkentés hatására. A képhez hozzátartozik, hogy a mintából kimaradt még 375 cég $(8,2 \%)$ azért, mert negatív saját tőkével rendelkeztek. Így összességében stratégiaváltás és jelentős teljesítménynövelés nélkül gyakorlatilag a cégek 45 százaléka növekedésre képtelen vagy nincs ilyen szándéka.

6. táblázat

A ROI értékei a tulajdonos szerint

\begin{tabular}{|l|c|c|c|c|}
\hline \multirow{2}{*}{} & \multicolumn{2}{|c|}{2010} & \multicolumn{2}{c|}{2014} \\
\cline { 2 - 5 } & Magyar & Külföldi & Magyar & Külföldi \\
\hline Medián & $14,58 \%$ & $18,16 \%$ & $13,72 \%$ & $18,22 \%$ \\
\hline Átlag & $17,70 \%$ & $21,17 \%$ & $16,26 \%$ & $20,88 \%$ \\
\hline
\end{tabular}

A kép csak kicsit differenciáltabb akkor, amikor a hazai és a külföldi tulajdonúak teljesítményét és magatartását külön vizsgáljuk. Ezt mutatják a ROI átlagos és medián értékei 2010-re és 2014-re. (6. táblázat)

A külföldiek hatékonyabbak voltak már 2010-ben is, de a magyarok lemaradása 2014-re növekedett. A növekedés szempontjából fontos ROE kritikus értéke alapján 2014-ben csak tizedszázalékos eltérés van $(33,5$, illetve 33,3) a 10 százalék alattiak arányában. A nagyobb különbség az osztalékok után, a mérleg szerinti eredmények alapján (MSZE) alakult ki. (4. ábra)

4. ábra

A Mérleg szerinti eredmény/Saját tőke mutató megoszlása tulajdonos szerint 2010 és 2014

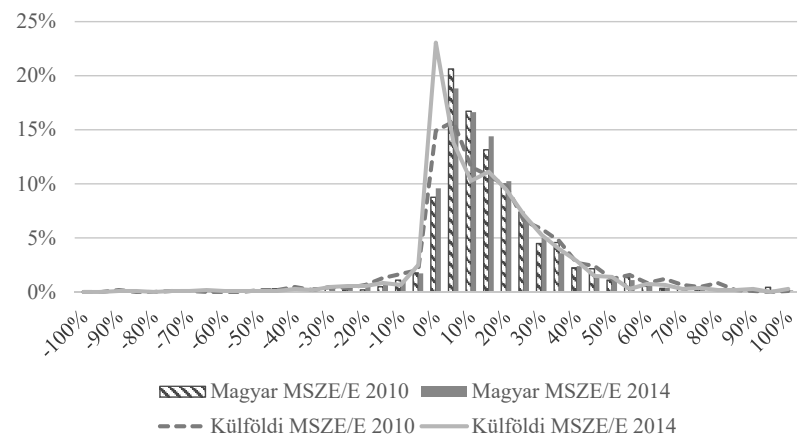

A magasabb hatékonyság ellenére, a külföldi tulajdonú cégek kevésbé növekedésorientáltak, a magasabb megtermelt jövedelemből kevesebbet hagynak a vállalatban, kevesebbet fordítanak bővítésre. Sokan és növekvő számban vannak a kritikus 10, illetve az 5 százalék alatt. Az utóbbiaknál már a szinttartás is veszélybe kerülhet. (7. táblázat)

\section{7. táblázat}

\section{Különbség a hazaiak és a külföldi tulajdonúak között (\%)}

\begin{tabular}{|l|c|c|c|c|}
\hline \multirow{2}{*}{} & \multicolumn{2}{|c|}{ Magyar } & \multicolumn{2}{c|}{ Külföldi } \\
\cline { 2 - 5 } & 2010 & 2014 & 2010 & 2014 \\
\cline { 2 - 5 } & \multicolumn{2}{|c|}{10 százalékos érték alatt lévők aránya } \\
\hline MSZE/E & 51,2 & 50,1 & 51,2 & 54,1 \\
\hline & \multicolumn{3}{|c|}{5 százalékos érték alatt lévők aránya } \\
\hline MSZE/E & 13,9 & 15,7 & 26,8 & 30,0 \\
\hline
\end{tabular}

Figyelemre méltó, hogy a külföldi tulajdonú cégeknél 2014 rosszabb helyzetet mutat, mint 2010. Ugyanakkor érdemi különbség a növekedési lehetőségek és szándékokban a tulajdon alapján nem mutatható ki. Miután a külföldiek még hatékonyabbak is, érdemes megvizsgálni az osztalékpolitikát a két csoportra elkülönítetten is. (8. táblázat)

Az osztalékot fizetök aránya mindenütt nőtt és igen magas a kifizetési ráta is. Ráadásul a ténylegesen osztalékot fizetők a hatékonyabb cégek. A magyar tulajdonúaknál a saját tőke hozama 20,9 (2010) és 15,2 (2014) százalék volt, aminek a 65, illetve 60 százalékát fizették ki, vagyis 
a vállalatban maradó sajáttőke-növekmény átlagban kevesebb volt 10 százaléknál. A magyar tulajdonúaknál az osztalékot nem fizetők az alacsony hozam (5,0, illetve 0,7 százalék) miatt nem is voltak abban a helyzetben, hogy fizessenek, hisz ezt az infláció és vélhetően a banki hitelek miatt sem nagyon tehették meg.

Az osztalékot fizető külföldi tulajdonúaknál a 27-30 százalékos sajáttőke-megtérülés ellenére nem fejlesztenek, helyette közel 100 százalékot kivettek az adózott eredményböl. A kevésbé hatékonyak 4,1, illetve 10,3 százalékos ROE-átlaggal nem vettek ki osztalékot, a megtermelt eredmény mértéke azonban nem kecsegtet dinamikus növekedési lehetőséggel, legalábbis a pénzügyi források oldaláról.

\section{8. táblázat}

\section{Az osztalékfizetés jellemzői a tulajdon szerint}

\begin{tabular}{|c|c|c|c|c|}
\hline & \multicolumn{2}{|c|}{$\begin{array}{l}\text { Külföldi: } \\
1569 \text { cég }\end{array}$} & \multicolumn{2}{|c|}{$\begin{array}{l}\text { Magyar: } \\
2597 \text { cég }\end{array}$} \\
\hline & 2010 & 2014 & 2010 & 2014 \\
\hline ROE (\%) & 13,1 & 16,2 & 9,4 & 12,5 \\
\hline Adózott eredmény (Mrd Ft) & 1151 & 1487 & 378 & 556 \\
\hline Kifizetett osztalék (Mrd Ft) & 912 & 846 & 152 & 275 \\
\hline $\begin{array}{l}\text { Osztalék/adózott eredm. } \\
(\%)\end{array}$ & 79,2 & 56,9 & 40,2 & 49,4 \\
\hline \multicolumn{5}{|c|}{$\begin{array}{r}\text { Az osztalékot fizetők jellemzői } \\
\end{array}$} \\
\hline Osztalékot fizetők száma & 459 & 597 & 993 & 1185 \\
\hline $\begin{array}{l}\text { Osztalékot fizetők aránya } \\
(\%)\end{array}$ & 29,3 & 38,0 & 38,7 & 46,1 \\
\hline ROE (\%) & 30,9 & 27,0 & 20,9 & 15,2 \\
\hline Adózott eredmény (Mrd Ft) & 911,6 & 876,7 & 234,2 & 454,8 \\
\hline $\begin{array}{l}\text { Osztalék/adózott eredm. } \\
(\%)\end{array}$ & 100 & 96 & 65 & 60 \\
\hline $\begin{array}{l}\text { ROE, osztalékot nem fize- } \\
\text { tők (\%) }\end{array}$ & 4,1 & 10,3 & 5,0 & 0,7 \\
\hline
\end{tabular}

A kép nem jobb, sőt inkább aggasztó, ha azokat a tökemozgásokat, tőkeemeléseket és leszállításokat vizsgáljuk, amit ez a folyamatosan múködő és az átlagnál nagyobb teljesítményủ vállalati kör végrehajtott a vizsgált időszakban. (9. táblázat)

\section{9. táblázat}

\section{A tőkeemelés és a tőkekivonás a vállalatoknál}

\begin{tabular}{|lccccc|}
\hline & 2010 & 2011 & 2012 & 2013 & 2014 \\
Tőkekivonás (Mrd Ft) & 604 & 729 & 1336 & 539 & 406 \\
Elsö 10 aránya (\%) & 0,81 & 0,84 & 0,84 & 0,51 & 0,53 \\
Tökekivonók száma & 589 & 563 & 783 & 610 & 612 \\
Tőkeemelés (Mrd Ft) & 503 & 641 & 284 & 453 & 568 \\
Első 10 aránya (\%) & 0,5 & 0,57 & 0,64 & 0,66 & 0,47 \\
Tőkeemelők száma & 758 & 605 & 412 & 668 & 717 \\
Nettó hatás (Mrd Ft) & -101 & -88 & -1052 & -86 & 162 \\
\hline
\end{tabular}

Gyakorlatilag abban a vállalati körben, amely a magyarországi nem pénzügyi vállalkozások között a külföldiek befektetéseinek 52,5 százalékát (2013) birtokolták, nettó tőkekivonás történt, azon túl, hogy a megtermelt jövede- lem nagy részét is osztalékként kiosztották. Ugyanakkor az első tíz vállalat aránya mindkét területen rendkívül nagy, ami mögött akár egyedi kormányzati megállapodások, illetve a kivonásnál egyedi vállalati problémák (például Nokia) is állhatnak.

Összességében a négy év alatt osztalékként és a tökeemelések és leszállítások szaldójaként mai árfolyamon számolva a teljes vállalati körből 23-24 milliárd eurós tőkekivonás történt. A külföldiek abszolút összegben, részben a nagyobb részarányukból is következően több pénzt vontak ki, viszont a magyar tulajdonúak nagyobb és növekvő arányban vettek ki osztalékot, elérve az adózott eredmény 60-65 százalékát. A szokatlan vállalati magatartás magyarázatát keresve megvizsgáltunk más lehetséges differenciáló tényezőket is. (10. táblázat)

\section{0. táblázat}

\section{A 10 százalék alatti cégek aránya néhány vállalati jellemző alapján}

\begin{tabular}{|l|c|c|c|c|}
\hline & ROI & ROE & MSZE/E & (Töke+MSZE)/E \\
\hline Alacsony bér & 37,8 & 36,6 & 51,9 & 51,2 \\
\hline Magas bér & 27,7 & 28,9 & 52,6 & 51,7 \\
\hline Belföldi fókusz & 38,0 & 36,8 & 56,4 & 56,0 \\
\hline Export fókusz & 24,6 & 26,4 & 43,5 & 42,0 \\
\hline 50 fő alatt & 42,3 & 41,8 & 60,6 & 59,6 \\
\hline 50 fö felett & 28,3 & 28,4 & 47,1 & 46,5 \\
\hline
\end{tabular}

Az iparági átlagbérhez viszonyított vállalati bérszint alapján a magasabb bérüek jobb teljesítményt (ROI és ROE) nyújtanak, ugyanakkor e cégek még inkább tőkekivonók, ezért rendre többen vannak a saját tőke változása alapján a 10 százalékos szint alatt. Az alacsony bérűeknél a tőkekivonás a vállalatoknak csak a 14,6 (51,2-36,6), míg a magas bérüeknél 22,8 (51,7-28,9) százalékát juttatta a 10 százalékos határ alá. Összességében azonban a bérek szintje alapján nem látszik érdemi differencia a növekedési szándékban.

Az exportfókuszú cégek hatékonyabbak és kevesebben kerülnek közülük az osztalék és tőkemüveletek után a 10 százalékos szint alá. Ugyanakkor itt is van 15,6 százalék $(42,0-26,4)$ gyarapodás a növekedést kevéssé preferálók számában. Mégis összességében ez az a vállalati kör, amelyik a tulajdonosi döntések után is a legnagyobb növekedési potenciállal - és vélhetően szándékkal is rendelkezik.

Ennek az ellenkezője igaz az 50 fő alatti foglalkoztatottal rendelkezők csoportjára. Náluk már a ROI alapján is a legmagasabb a 10 százalék alattiak aránya, vagyis legkevésbé termelik ki a növekedés forrásait, amit az osztalékkifizetések még tovább mérsékelnek. Ebben a vállalati méretben van a legnagyobb lehetőség az adóelkerülésre, így nem lehet azt egyértelmüen megállapítani, hogy e cégek kevésbé hatékonyak, de ez a tulajdonosi szándékok irányát nem változtatja meg. Közel 60 százalékuk növekedési potenciálja igen alacsony. 


\section{Együttes hatások vizsgálata}

Miután a különféle változók növekedési ütemre gyakorolt egyedi hatását azonosítottuk, megvizsgáltuk azt is, hogy az egyes tényezők befolyása egyidejüleg is fennáll-e. Azt ellenőriztük, hogy az egyedi hatások egyes esetekben nemcsak látszólagosak-e, vagyis csupán a magyarázó változók közötti kapcsolatnak volnának betudhatóak.

Ehhez minden vizsgált évre lineáris regressziókat becsültünk úgy, hogy valamennyi felmerült változót bevontuk, majd a nem szignifikáns együtthatók közül a leggyengébbet elhagytuk és a regressziót újrabecsültük (backward eljárás). Az eljárást addig folytattuk, amíg csak szignifikáns együtthatójú változók maradtak a becsült regresszióban.

A kapott modellek adatait a 11. táblázat mutatja. A magyarázott változó minden esetben a mérleg szerinti eredmény és az év eleji saját tőke hányadosa volt (g), azaz a regressziók a tőkeemelés és leszállítás hatásait meg sem kísérelték megragadni, hiszen az elmélet alapján az ilyen döntések mögött inkább egyedi (fejlesztési igény, likviditási gond), illetve makrogazdasági vagy iparági hatások (ágazati fellendülés, politikai kockázat növekedése) állhatnak, amelyeket a bevont magyarázóváltozók nem fedhetnek le.

Az egyes változók mindig az adott évben felvett értékeikkel szerepeltek a regresszióban, kivéve a létszámot. A cégeket eredetileg a 2010-es állományadatok alapján soroltuk be méretkategóriába, ám ez a változó a többi tényezővel egyidejűleg vizsgálva már nem mutatkozott szignifikánsnak a 2010-2013 időszakban. Szignifikáns lett azonban 2014-re, ami azért volt meglepö, mert ez az esztendő volt a legtávolabb a besoroláshoz alapul vett létszámértéktől. Tekintettel arra, hogy a cégek létszáma az évek során nagyot változhatott, a besorolást a 2014-es létszámok alapján ismételten elvégeztük és e változóval is újrafutattuk a 2014-re vonatkozó regressziós becslést (2014b oszlop). Az eredmények robosztusságát mutatja, hogy az együtthatók és a teljes magyarázó erő így sem változott érdemben.

11. táblázat

A becsült lineáris regressziók együtthatói*

\begin{tabular}{|l|r|r|r|r|r|r|}
\hline & $\mathbf{2 0 1 0}$ & \multicolumn{1}{c|}{$\mathbf{2 0 1 1}$} & \multicolumn{1}{c|}{$\mathbf{2 0 1 2}$} & $\mathbf{2 0 1 3}$ & $\mathbf{2 0 1 4 a}$ & $\mathbf{2 0 1 4 b}$ \\
\hline Konstans & $-0,019$ & $-0,032$ & $-0,012$ & $-0,006$ & $-0,006$ & $-0,004$ \\
\hline ROI & 0,644 & 0,631 & 0,621 & 0,591 & 0,556 & 0,552 \\
\hline Magyar & $2,86 \%$ & $3,14 \%$ & $2,72 \%$ & $2,53 \%$ & $4,22 \%$ & $4,23 \%$ \\
\hline Magas bér & & & & $-1,71 \%$ & $-1,66 \%$ & $-1,64 \%$ \\
\hline $\begin{array}{l}\text { Export } \\
\text { fókusz }\end{array}$ & $3,12 \%$ & $3,09 \%$ & $2,69 \%$ & $2,99 \%$ & $3,16 \%$ & $3,07 \%$ \\
\hline $\begin{array}{l}50 \text { fó } \\
\text { alatti* }\end{array}$ & & & & & $-1,50 \%$ & $-1,78 \%$ \\
\hline $\mathrm{R}^{2}$ & $38,40 \%$ & $31,20 \%$ & $31,50 \%$ & $33,10 \%$ & $32,30 \%$ & $32,30 \%$ \\
\hline
\end{tabular}

* Magyarázott változó: MSZE/Saját tőke év elején

A modellek magyarázó ereje $\left(\mathrm{R}^{2}\right)$ ugyan nem túl magas (11. táblázat), de igen stabil: a bevont változók együttesen a variancia 31-38 százalékát magyarázzák, azaz a megragadott hatások semmiképpen sem elhanyagolhatóak, mi- közben bőven hagynak helyet a direkt vállalati teljesítményen kívüli egyéb makrogazdasági, iparági vagy egyedi vállalati hatásoknak. Az együtthatókból kiolvasható legfontosabb következtetéseink a következők.

(1a) A magasabb tőkearányos hozam (ROI) az elmélet alapján kialakított várakozásoknak megfelelöen nagyobb lehetőséget biztosít a növekedésnek, azonban (1b) a vizsgált időszakban e változó szerepe csökkent: 2014-re kevésbé volt igaz, hogy a jobban teljesítő cégek gyorsabban is növekednek (az együttható abszolút értéke csökkent). Míg 2010-ben egy százalékkal magasabb tőkearányos hozam 0,64 százalékkal magasabb belső forrású növekedést eredményezett, 2014-re ugyanaz már csak 0,56 (vagy $0,55)$ százalék volt.

(2) A magyar vállalatok inkább kívánnak növekedni, mint a külföldi kézben lévők. A hazai cégek 2010-ben azonos körülmények között 2,8 százalékkal gyorsabban növekedtek, mint a külföldiek, s ez a különbség némi viszszaesés után 2014-re már 4,2 százalékra kapaszkodott. Megfordítva: azonos tőkearányos hozamból a külföldi tulajdonosok magasabb osztalékot vonnak ki, mint a magyarok, vagy a magyarok kevésbé optimalizálnak globálisan, így inkább fektetnek be itthon.

(3) Az ágazati átlagnál magasabb bért fizető, vagyis a feltehetőleg képzettebb dolgozókkal magasabb hozzáadott értékü tevékenységet végző társaságok 2013-tól 1,7 százalékkal kisebb visszaforgatást hajtottak végre, mint a kevésbé képzett munkaerőt alkalmazók. Ez azt jelenti, hogy az utóbbi években a gazdaságon belül emelkedett a kisebb hozzáadott értékü (jellemzően élesebb versenynek kitett és kevésbé jövedelmező) tevékenységek aránya.

(4) Az exportfókuszú (folyamatos kivitellel bíró, 2013ban bevételük legalább 25 százalékát exportból elérő) cégek változatlan körülmények között a teljes vizsgált idöszakban mintegy 3,1 százalékkal gyorsabban nőttek belső forrásból, mint a belpiacra koncentrálók. Úgy tünik az exportpiacokon sokkal nagyobb növekedési lehetőségek kínálkoznak és több jó projektet sikerül találni, mint a hazai gazdaságban.

(5) Az 50 fönél kevesebbet foglalkoztató cégek semmilyen többletnövekedési hajlandóságot sem mutattak a 2010-2013 időszakban. Sőt, a várakozásokkal ellentétben 2014-ben éppen a legkisebb cégek forgattak vissza kevesebbet: minden egyéb tényező változatlansága esetén a többi céghez képest 1,5-1,8 százalékkal lassabban gyarapodott belső forrásból a saját tőkéjük.

Összegezve az adatok alapján a hazai gazdaság hajtóerejét az utóbbi években a hazai tulajdonú cégek, a kisebb hozzáadott értékü tevékenységet végző társaságok, a kivitelre koncentráló vállalatok és egyben a nagyobb vállalkozások adták. A belső piacok fejlesztésére, a KKV-k helyzetbe hozására és a külföldi társaságokra építő gazdaságpolitika sikeressége ezek alapján igen korlátozott volt.

\section{Miért szerény a hazai növekedés?}

A nemzetközi összevetésben gyengébb hazai növekedést indokolhatja a nagyobb GDP-centralizáció is. A magas 
elvonás elveszi a külföldi befektetők kedvét és jócskán csökkenti a már működő társaságok mozgásterét. Nem zárható ki az, hogy a hazai vállalatok állami és önkormányzati terhei magasak, ezért alacsonyabb jelentős részüknél a megtérülés.

A vállalatok több, mint 40 százaléka 10 százalék alatti hozamot produkál még a könyv szerinti érték alapján is. A hitelek tőkeköltségét figyelembe véve ez az elvárton felül aligha eredményez többlet tulajdonosi hozamot vagy csupán minimálisat, ami megjelenhet a beruházási aktivitásban is. A többség esetében ez azonban nem áll, hisz a mintánk átlagban is magasabb teljesítményt mutat mind a bruttó, mind a nettó működési eredmény/állóeszköz mutatóban, mint az OECD-országok átlaga.

A beruházási aktivitás mégis rosszabb, mint ami a vállalat által megtermelt jövedelem alapján finanszírozható lenne. Amikor a beruházás/saját tőke mutatót vizsgáltuk, akkor a medián és még a harmadik kvartilis vállalatánál is kisebb volt a beruházás, mint a saját tőke növekedése. Vagyis még további beruházásokat tudtak volna hitel nélkül is megvalósítani. Nyilván ez nem racionális az alacsony hozamú vállalatokra, de a többiek számára ez lehetőség lenne, különösen akkor, ha azt is figyelembe vesszük, hogy az új beruházások jó eséllyel magasabb technikai színvonalat valósítanak meg, ami többlet eredmény forrása lehet.

A beruházások elmaradása különösen a hatékonyabb külföldi tulajdonú cégeknél jelentős, ami független az elért, akár magas jövedelmezőségtől. E cégek globálisan optimalizálnak, ami magyarázhatja a külföldiek osztalékszintjét, vagyis a kisebb növekedési szándékot.

Emellett lehet erre a magatartásra olyan magyarázat is, amely pénzügyi mutatókkal nem támasztható alá. Ok lehet az üzleti környezet, a bizalomvesztés, az ország romló versenyképessége. Ok lehet a piaci verseny háttérbe szorulása, de okozhatják a kedvezőtlen belső piaci kilátások is, hisz még mindig nem értük el fogyasztásban a válság elötti szintet.

Ok lehet a gazdaságpolitika, illetve annak kiszámíthatósága, vagy a gazdasági működést szabályozó jogszabályok gyakori változása. Mindezek nem várt pozícióváltozásokat, átrendeződéseket okoznak, amelyet az üzleti világ kockázatként ítél meg, ami akár a korábbi hozamelvárást is megemelheti. Ilyen kockázatot jelent a tulajdonjogokkal kapcsolatos növekvő bizonytalanság is, amelyet számos gyors, akár teljes iparágakat (trafik, szerencsejáték, föld, kereskedelem) is átrendező kormányzati intézkedések táplálnak.

\section{Gazdaságpolitikai megfontolások}

Nem kerülhető el a magyar növekedési modell felülvizsgálata. Ha nem sikerül az elsődleges jövedelmek centralizációját csökkenteni (ezt javasolja Eftimoski, Josifovska és Josheski (2015) is), azt néhány százalékkal a vállalatok javára átrendezni, akkor a magyar gazdaság növekedési pályája tartósan alacsonyabb lesz, mint a környező országoké.

A hazai szabályozási környezetben vissza kellene szerezni a versenyképességünket. Ez kiszámíthatóságot, a túlszabályozás egyszerüsítését, a közbeszerzések átláthatóságát és a korrupció csökkentését egyaránt jelenti. Ezek nélkül nincs meg a tőkevonzó képesség, vagy azt csak egyedi kormányzati intézkedésekkel, támogatásokkal lehet fenntartani, ami ellentmond a centralizáció csökkentésének.

Ahogy vizsgálatában Halpern és Oblath (2014) is rámutat, a hazai magánszektor nettó beruházásainak alacsony szintjét kellene emelni ahhoz, hogy tartósan gyorsítani lehessen a gazdasági növekedést. Elemzéseink azonban azt mutatják, hogy a jobb és stabil vállalatok még a lehetőségeiket sem használják ki, tehát nem töke, nem forrás oldalon van akadálya a beruházások növekedésének.

Bayar (2015) szerint az FDI-beáramlás és a külföldön dolgozók hazautalásainak bátorítása és könnyítése lehet a regionális növekedés gyorsításának egyik módja. Balatoni és Pitz (2012) ennek kapcsán megjegyzik: a müködőtőke-beáramlásból származó előnyök az emberi tőke rendelkezésre álló mennyiségének, a fizikai és pénzügyi infrastruktúrának, a makrogazdasági stabilitásnak, valamint az intézményrendszernek a függvényében volnának jobban kiaknázhatók. Másképpen megfogalmazva: erősíteni kellene a piaci mechanizmusokat, egy kis, nyitott gazdaság nem mondhat le erröl, és nem is zárhatja ki ennek a hatását.

Egyetértve Halpern és Oblath (2014) felvetésével, viszsza kellene szerezni a politikának a bizalmat, részben a tulajdon biztonságának biztosításával, mert e nélkül még a magyar tulajdonú vállalatok is növekvő tőkekivonást hajtanak végre azért, hogy a tulajdonosok tartalékokat képezzenek maguknak.

Jasiński és Mielcarz (2013) alapján ugyanakkor nem csupán a vállalkozások és befektetők, de a lakosság gazdaságba vetett bizalmának erösítése ugyancsak kulcsfontosságú a válságtűrő képesség javításában. Eftimoski, Josifovska és Josheski (2015) ehhez kapcsolódva a szabadságjogok megerősítését javasolják a gazdasági aktivitás és így a foglalkoztatás tartós fellendítéséhez.

\section{Felhasznált irodalom}

Afonso, A. - Schuknecht, L. - Tanzi, V. (2006): Public sector efficiency: evidence from new EU member states and emerging markets. ECB Working Paper, Series No. 581, January, http://www.ecb.europa.eu/pub/pdf/ scpwps/ecbwp581.pdf Letöltés: 2015. június 18.

Báger G. (2015): Investment Ebb and Flow in the Hungarian Economy. Public Finance Quarterly, (0031-496X), 60, 2, p. 147-170.

Balatoni A. - Pitz M. (2012): A müködő tőke hatása a bruttó nemzeti jövedelemre Magyarországon. Közgazdasági Szemle, 59, p. 1-30.

Bayar, Y. (2015): Impact of Remittances on the Economic Growth in the Transitional Economies of the European Union. Petroleum - Gas University Of Ploiesti Bulletin, Technical Series, 67, 3, p. 1-10.

Brealey, R. A. - Myers, S. C. (2005): Modern vállalati pénzügyek. Budapest: Panem Kiadó

Eftimoski, D. - Josifovska, A. - Josheski, D. (2015): Does democracy and government policy affect labor market 
outcomes in CEE countries? Journal of Sustainable Development (1857-8519), 5, 12, p. 4-22.

Halpern, L. - Oblath, G. (2014): A gazdasági stagnálás „színe” és fonákja. Közgazdasági Szemle, 6, p. 757-800.

Higgins, R. C. (2012): Analysis for Financial management. New York: McGraw-Hill

Jasiński, T. - Mielcarz, P. (2013): Consumption as a Factor of Polish Economic Growth During the Global Recession of 2008/2009: A Comparison with Spain and Hungary. Contemporary Economics, 7, 2, p. 5-16.

Kaitila, V. (2014): Transnational Income Convergence and National Income Disparity: Europe, 1960-2012. Journal of Economic Integration, 29, 2, p. 343-371.

Kónya I. (2015): Több gép vagy nagyobb hatékonyság? Közgazdasági Szemle, 62, p. 1117-1222.

KSH (2016a): 3.1.3. Az egy före jutó bruttó hazai termék (GDP) értéke (1995-). https://www.ksh.hu/docs/hun/xstadat/xstadat_eves/i_qpt016.html, Letöltés: 2016. május 9.

KSH (2016b): Egy före jutó GDP (1995-2015). https:// www.ksh.hu/docs/hun/eurostat tablak/tabl/tsdec100. html, Letöltés: 2016. május 9.

KSH (2016c): 3.1.16. A nemzetgazdaság integrált számlái, 2013 - ESA2010. http://www.ksh.hu/docs/hun/xstadat/xstadat_hosszu/int2013a.html, Letöltés: 2016. június 19.
KSH (2016d): 3.1.9. A bruttó hazai termék (GDP) végső felhasználása folyó áron. http://www.ksh.hu/docs/ hun/xstadat/xstadat_evkozi/e_qpf001a.html, Letöltés: 2016. június 19.

Muraközy L. (2015): Államok kora: Az európai modell. Budapest: Akadémiai Kiadó

OECD (2014): OECD Economic Surveys: Hungary 2014. Paris: OECD Publishing, DOI: http://dx.doi.org/10.1787/ eco surveys-hun-2014-en, Letöltés: 2016. június 5.

OECD (2016a): Non-financial accounts by sectors, https:// stats.oecd.org/Index.aspx?DataSetCode=SNA_TABLE14A, Letöltés: 2016. június 5.

OECD (2016b): Revenue Statistics - Comparative tables, https://stats.oecd.org/Index.aspx?DataSetCode=REV, Letöltés: 2016. június 5.

Plaschinsky, G. (2016): Why Poland outperformed its Visegrad counterparts is 2009-2012? http://www. academia.edu/7861471/Why_Poland_outperformed_ its_Visegrad_counterparts_in_2009-2012, Letöltés: 2016. június $\overline{5}$.

Reszegi L. - Juhász P. (2014): A vállalati teljesítmény nyomában. Budapest: Alinea Kiadó

Witte, K. - Moesen, W. (2010): Sizing the government. Public Choice, Springer, vol. 145, 1, October, p. 39-55. 